\title{
DPM Dua Mode Dilengkapi Thermohygrometer dan Pemilihan Tekanan (Positive Pressure)
}

\author{
Ketut Dyah Kusumadewi \#, Syaifudin, Tri Bowo Indrato
}

Jurusan Teknologi Elektro-medis Poltekkes Kemenkes, Surabaya

Jl. Pucang Jajar Timur No. 10, Surabaya, 60245, Indonesia

\#diyahkusuma226@gmail.com, Nyong74@yahoo.com, tribowo.tem81@gmail.com

\begin{tabular}{l}
\hline \multicolumn{1}{c}{ Info Artikel } \\
\hline Penerimaan Artikel: \\
Diterima 9 Maret 2019 \\
Revisi 15 Des 2020 \\
Terbit 18 Des 2020 \\
\hline Katakunci: \\
Kalibrasi, Tensismeter \\
dilengkapi suhu \\
kelembaban.
\end{tabular}

\section{Abstrak}

Kalibrasi merupakan suatu kegiatan teknis yang terdiri atas penetapan, penentuan suatu atau lebih sifat dan karakteristik dari suatu produk, proses atau jasa sesuai dengan prosedur khusus yang telah ditetapkan. Digital Pressure Meter (DPM) merupakan alat yang digunakan untuk mengukur tekanan positif dan negatif pada alat Kesehatan. Tujuan dibuatnya alat Digital Pressure Meter (DPM) Dua Mode dilengkapi Thermohygrometer dan Pemilihan Tekanan(Positive Pressure) sebagai solusi untuk menciptakan perangkat pemantauan tekanan darah yang lebih informatif efektif serta akurat dalam pengukurannya. Kontribusi penelitian ini adalah sistem dapat dijalankan dengan menggunakan sensor tekanan tiup, hasil ukur bisa dikonversi ke satuan kPa dan ditampilkan di LCD TFT Nextion 2,4 inch. Agar sistem berjalan maka diperlukan tekanan tiup yang sesuai dengan alat tensimeter itu sendiri. Menggunakan sensor MPX 5050GP sebagai sensor tekanan positif. Membutuhkan tekanan maksimal $300 \mathrm{mmHg}$. Menggunakan sensor DHT 22 untuk suhu kelembaban. Alat ini juga di lengkapi degan timer uji kebocoran. Display yang digunakan pada modul ini adalah LCD TFT Nextion 2,4 inch Setelah melakukan proses pengukuran ke alat tensimeter air raksa sebanyak 6 kali didapatkan hasil terkecil $0 \mathrm{mmHg}$ pada tekanan $0 \mathrm{mmHg}$ dan yang terbesar $298.0 \mathrm{mmHg}$ pada tekanan 300 $\mathrm{mmHg}$. Simpangan rata-rata terbesar ini dikarenakan adanya kebocoran tekanan antara selang penghubung output modul dan penghubung ke alat tensimeter. Berdasarkan pengambilan data suhu kelembaban yang dilakukan pada ruangan diperoleh $31^{\circ} \mathrm{C}$ pada suhu dan $87 \%$ pada kelembaban. Dari penelitian ini Rangkaian keseluruhan yang dibuat sudah sesuai dengan kebutuhan modul DPM Hasil penelitian menunjukkan bahwa modul bisa digunakan untuk proses kalibrasi pada alat tensimeter.

\begin{abstract}
Calibration is a technical activity consisting of the determination, determination of one or more of the characteristics and characteristics of a product, process or service in accordance with specific procedures that have been determined. Digital Pressure Meter (DPM) is a tool used to measure positive and negative pressure on health tools. The purpose is to make the two mode Digital Pressure Meter (DPM) equipped with Thermohygrometer and Pressure Pressure (Positive Pressure) as a solution to create a blood pressure monitoring device that is more informative effective and accurate in its measurement. The contribution of this study is that the system can be run by using an inflatable pressure sensor, the measurement results can be converted to kPa units and displayed on a 2.4 inch TFT LCD Nextion. In order for the system to run, it is necessary to have blow pressure according to the tensimeter itself. Using the MPX $5050 G P$ sensor as a positive pressure sensor. Requires a maximum pressure of $300 \mathrm{mmHg}$. Using a DHT 22 sensor for humidity temperature. This tool is also equipped with a leak test timer. The display used in this module is the 2.4 inch TFT Nextion LCD. After measuring 6 times the mercury tensimeter, the smallest result is $0 \mathrm{mmHg}$ at $0 \mathrm{mmHg}$ and the largest is 298.0 $\mathrm{mmHg}$ at $300 \mathrm{~mm} \mathrm{Hg}$ pressure. The largest mean deviation is due to a pressure leak between the module output connecting hose and connecting to the tensimeter device. Based on data retrieval of humidity temperature carried out in the room obtained $31^{\circ} \mathrm{C}$ at temperature and $87 \%$ at humidity. From this research, the overall series made is in accordance with the needs of the DPM module. The results of the study indicate that the module can be used for the calibration process on a tensimeter device.
\end{abstract}

\author{
Penulis korespondensi: \\ Tri Bowo Indrato \\ Jurusan Teknologi Elektro-medis \\ Poltekkes Kemenkes, Surabaya \\ J1. Pucang Jajar Timur No. 10, Surabaya, 60245, Indonesia \\ Email: tribowo.tem81@gmail.com
}

This work is an open access article and licensed under a Creative Commons Attribution-ShareAlike 4.0 International License(CC BY-SA 4.0).

\section{Pendahuluan}

Digital Pressure Meter (DPM) merupakan alat yang digunakan untuk mengukur tekanan positif dan negatif pada alat kesehatan dalam bentuk cair ataupun gas untuk membantu dalam perbaikan dan kontrol kualitas. Cara kerja alat ini adalah dengan mengkonversikan nilai dari sensor tekanan diubah dan ditampilkan pada display. Banyak sekali bentuk, jenis, dan fungsi Digital Presure Meter, seperti yang berfungsi hanya sebagai tekanan tiup dan tekanan hisap. Dalam penelitian ini, penggunaan DPM yang berkaitan dengan kalibrasi pada tensimeter air raksa dan suction pump. Semua tensimeter harus diperiksa dan dikalibrasi oleh laboratorium terakreditasi setidaknya setiap tahun[1]. Pengukuran tekanan darah yang 
akurat membutuhkan penggunaan suatu sphygmomanometer akurat[2]. Tensimeter merupakan alat untuk mengukur tekanan darah yang sering digunakan pada dunia medis. Fungsinya sangat vital karena menjadi dasar bagi dokter untuk mendiagnosa kesehatan pasien. Keakuratan dari sphygmomanometer sangat bergantung pada melakukan perawatan yang benar dan proses kalibrasi peralatan ini. Salah satu kesalahan paling umum dalam pengukuran tekanan darah disebabkan dengan menggunakan sphygmomanometer yang tidak terkalibrasi dan penggunaan manset yang kurang tepat. Pemeliharaan dan kalibrasi sphygmomanometer yang tidak akurat adalah penyebab kesalahan sistematis dalam pengukuran tekanan darah[3].

Alat ukur tensimeter dan suction pump pernah dibuat dan diteliti sebelumnya dengan judul Portable Kalibrator Tensimeter Berbasis Mikrokontroller ATmega 8535 adalah Heru Wahyu Purnama (2014) Pada alat yang dibuat tersebut hanya satu tipe saja yaitu tensimeter air raksa dengan ditampilkan pada LCD karakter, tetapi alat ini tidak dilengkapi dengan tekanan hisap (Vacum pressure)[4]. Pada tahun 2015 Rosyi Dwi Putranti telah melakukan penelitian dengan judul "Analisis Dengan Tensimeter Jarum", pada analisa tersebut dinyatakan bahwa jumlah kebocoran pada tensimeter air raksa sebanyak $25 \%$ dari 16 alat yang diuji dengan kebocoran maksimal sebesar -77.6 $\mathrm{mmHg}$, jumlah kebocoran pada tensimeter jarum sebanyak $6.25 \%$ dari 16 alat yang diuji dengan kebocoran maksimal sebesar - 46mmHg, kebocoran tensimeter air raksa lebih tinggi dibandingkan dengan tensimeter jarum, sehingga penulis berpendapat untuk mengurangi terjadinya kebocoran dibutuhkan kalibrasi dan perawatan pada tensimeter tersebut[5]. Pada tahun 2017 Junia Dyah Permata Wibisono membuat tugas akhir dengan judul Digital Pressure Meter (DPM) Vacum Pressure dengan tampilan LCD karakter. Pada alat ini hanya menggunakan 1 (satu) mode saja yang digunakan hanya untuk suction pump[6]. Pada Tahun 2018 Yosep Kurniawan membuat tugas akhir tentang Digital Pressure Meter (DPM) dua mode yaitu tekanan positif dan tekanan hisap namun alat ini tingkat keakurasiannya masih relatif standart yaitu memiliki nilai selisih atau nilai koreksi sebesar $0-3 \mathrm{mmHg}$ [7]. Pada Tahun 2019 Mukhamad Ryan Nur Rohman membuat tugas akhir tentang Digital Pressure Meter (DPM) Tensimeter dan Suction Pump, namun alat ini masih memiliki kekurangan yaitu timer uji kebocoran yang digunakan saat melakukan pengukuran pada tensimeter dan kekurangan suhu, kelembapan dalam kalibrasi tensimeter maupun suction pump. Harus diperhatikan suhu, kelembapan ruangan karena dapat memengaruhi hasil pada saat melakukan pengukuran[8].

Kondisi lingkungan kalibrasi harus diatur sedemikian sesuai persyaratan metode kalibrasi. Ketika itu perlu suhu dan kelembaban konstan untuk memiliki kenyamanan yang diinginkan[9]. Tidak selamanya kalibrasi harus dilakukan pada ruang yang terkondisi dengan ketat[10]. Pengkondisian lingkungan kalibrasi biasanya dilakukan untuk kalibrasi peralatan yang mudah berubah akibat pengaruh suhu, kelembapan, getaran, cahaya, dan sebagainya. Untuk mengetahui suhu dan kelembapan pada saat proses kalibrasi sphygmomanometer dan suction pump dibutuhkan alat Thermohygrometer[11]Termohygrometer dapat digunakan untuk mengukur suhu dan kelembaban udara di dalam dan luar ruangan[12]. Tensimeter dikenalkan pertama kali oleh dr. Nikolai Korotkov, seorang ahli bedah Rusia, lebih dari 100 tahun yang lalu[13]. Tensimeter adalah alat pengukuran tekanan darah sering juga disebut sphygmomanometer.

Artikel ini terdiri dari 5 bagian, bagian II berisi metode dan pengembangan yang akan dilakukan. Bagian III, merupakan hasil-hasil yang didapatkan pada penelitian ini. Bagian IV adalah Pembahasan temuan-temuan dan Bagian $\mathrm{V}$ adalah kesimpulan.

\section{II BAHAN DAN METODE}

\section{A. Rancangan Penelitian}

Penelitian ini menggunakan pengukuran terhadap Tensimeter air raksa dengan setting tekanan positif ; $0 \mathrm{mmHg}$, $50 \mathrm{mmHg}, 100 \mathrm{mmHg}, 150 \mathrm{mmHg}, 200 \mathrm{mmHg}, 250 \mathrm{mmHg}$, $300 \mathrm{mmHg}$, yang kemudian bisa dikonversi satuan tekananya ke $\mathrm{kPa}$. Pengambilan data diulang selama 6 kali.

\section{1) Alat dan Bahan}

Penelitian ini menggunakan Sensor MPX 5050 GP berfungsi sebagai tekanan tiup. Sensor tekanan silikon monolitik yang dirancang untuk berbagai aplikasi, terutama yangmenggunakan mikrokontroler [14] [15] Dan sensor DHT 22 berfungsi sebagai sensor suhu, kelembaban DHT22 mampu menampilan nilai hingga satu angka dibelakang koma.[16] [17]. Output sensor MPX 5050 GP selanjutnya masuk ke input rangkaian buffer. Output dari rangkaian buffer lalu vec, output dan gnd dari kaki sensor DHT 22 kemudian masuk dan diproses ke Arduino Nano. Arduino Nano sebagai pengontrol dan pengendali[18]. Output Arduino Nano berupa tampilan pada LCD TFT Nextion 2,4 inch.[19][20].

\section{2) Percobaan}

Dalam studi ini, setelah desain jadi, dilakukan pengujian output Digital Pressure Meter (Positive Pressure) dengan tekanan $0 \mathrm{mmHg}, 50 \mathrm{mmHg}, 100 \mathrm{mmHg}, 150 \mathrm{mmHg}, 200 \mathrm{mmHg}$, $250 \mathrm{mmHg}, 300 \mathrm{mmHg}$, lalu dilakukan pengukuran dengan alat Tensimeter. Setiap pengaturan, dihitung untuk memvalidasi hasil penelitian ini.

\section{B. Blok Diagram}

Dalam penelitian ini, data Positive diperoleh dari selang manset dan selang pompa dari Tensimeter dengan beberapa tekanan yaitu $0 \mathrm{mmHg}, 50 \mathrm{mmHg}, 100 \mathrm{mmHg}, 150 \mathrm{mmHg}$, $200 \mathrm{mmHg}, 250 \mathrm{mmHg}, 300 \mathrm{mmHg}$, yang ditunjukkan pada Gambar. 1. Sensor MPX 5050 GP sebagai tekanan tiup. Output sensor selanjutnya masuk input rangkaian buffer sebagai penguat arus tanpa terjadi penguat tegangan. Output buffer selanjutnya masuk dan diproses ke Arduino Nano. Terdapat konversi dari $\mathrm{mmHg}$ to $\mathrm{kPa}$ yang akan diproses ke Arduino Nano juga. Setelah diproses menggunakan Arduino Nano, output berupa tampilan pada LCD TFT Nextion 2,4 inch. 


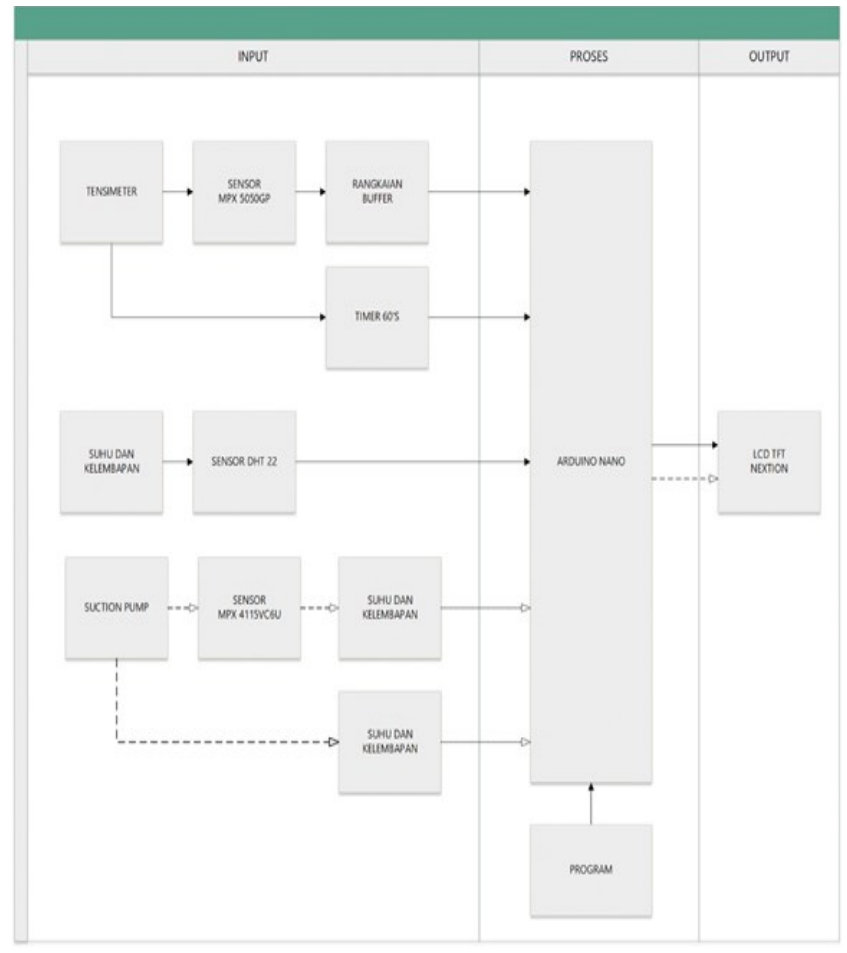

Fig. 1. Blok Diagram

Keterangan:

$=$ Tidak dibahas oleh penulis

$=$ Dibahas oleh penulis

\section{Tensimeter}

Pada proses kalibrasi, selang manset dan selang pompa dari tensimeter yang digunakan untuk bahan pengujian kalibrasi.

2. Sensor MPX 5050 GP

Sebagai sensor tekanan tiup. Output sensor selanjutnya masuk ke rangakaian Buffer.

3. Sensor DHT 22 sebagai sensor suhu kelembaban, vcc, output dan ground disambungkan pada pin Arduino nano.

4. Rangkaian Buffer

Sebagai penyangga, dimana prinsip dasarnya adalah penguat arus tanpa terjadi penguat tegangan. Output Buffer selanjutnya masuk dan diproses ke Arduino Nano.

5. Timer 60 detik yang berfungsi sebagai pewaktu untuk melakukan tes kebocoran pada saat melakukan pengukuran pada tensimeter.

6. Arduino Nano

Arduino Nano sebagai pengontrol dan pengendali. Output berupa tampilan pada LCD TFT Nextion 2,4 inch.

7. LCD TFT Nextion 2,4 inch

LCD TFT Nextion berfungsi sebagai display untuk menampilkan proses pengukuran, kalibrasi. Pada sistem alat Digital Pressure Meter, LCD menampilkan hasil tekanan dan konversi.

\section{Diagram Alir}

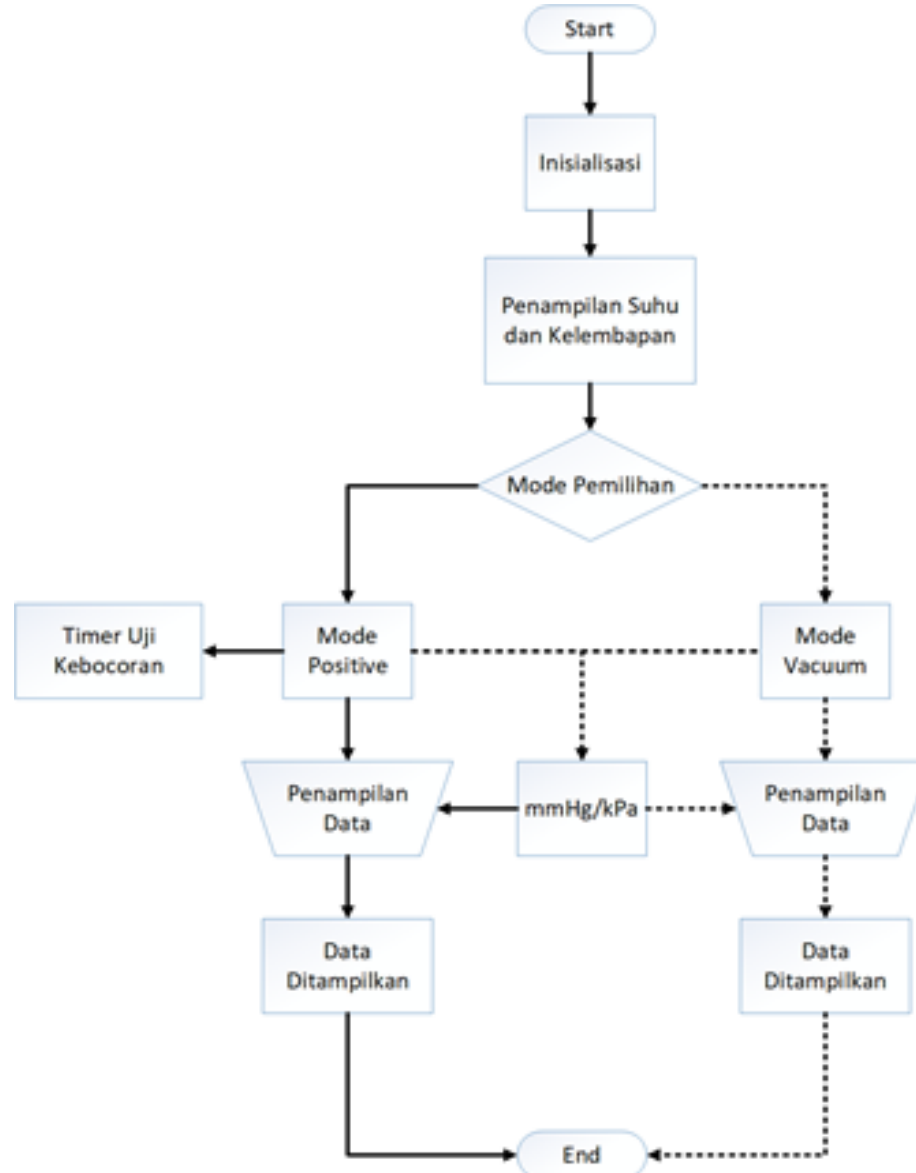

Fig. 2. Diagram alir

ditunjukkan pada Gambar. 2. Ketika modul di start maka terjadi inisialisasi, terjadi penampilan suhu, kelembaban, terdapat dua pemilihan mode yaitu mode positive dan vacuum ,Ketika memilih mode positive saat dilakukan pemompaan manual maka sensor MPX 5050 GP akan membaca dan hasil akan ditampilkan dalam pengukuran mode positive terdapat timer 60 detik untuk uji kebocoran. Dari hasil pembacaan tersebut dapat dikonvesi lagi satuan tekanan dari $\mathrm{mmHg} \mathrm{ke} \mathrm{kPa}$ lalu data ditampilkan pada LCD TFT Nextion 2.4 inch.

\section{Skematik Rangkaian}

1) Buffer Amplifier 


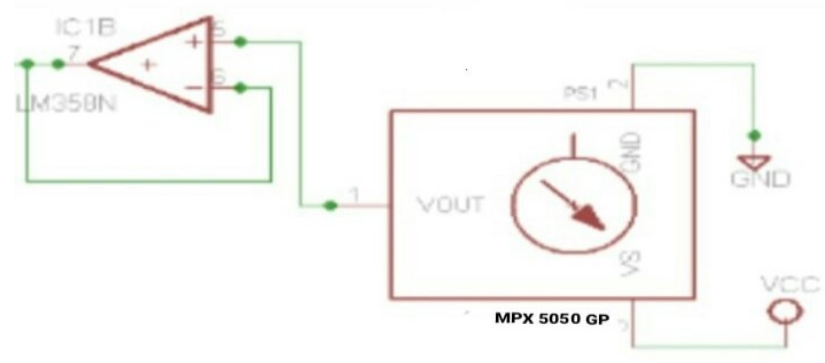

Fig. 3. Rangkaian Buffer

Rangkaian Amplifier Buffer, seperti yang ditunjukkan di atas, mendapat input dari sensor tekanan MPX5050GP positif.

2) $\mathrm{DHT} 22$

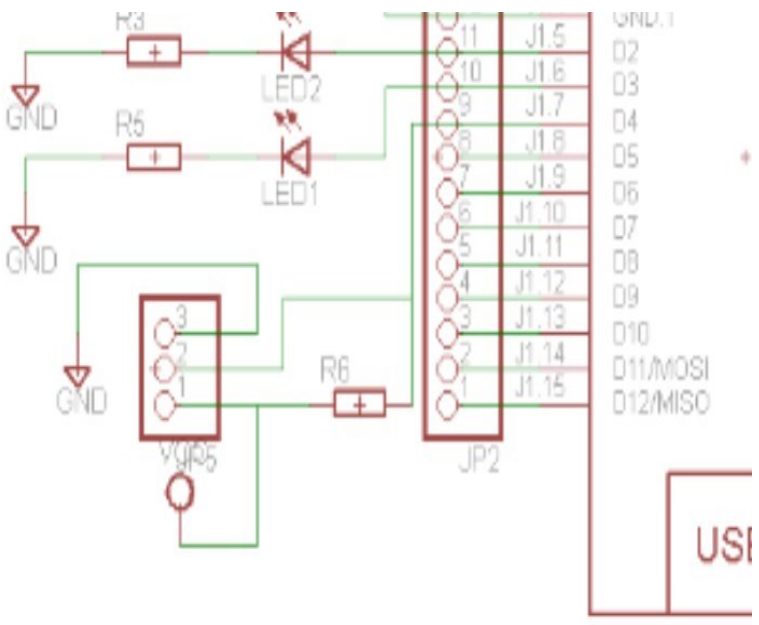

Fig. 4. Rangkaian DHT yang terhubung pada pin arduino

DHT 22 terhubung ke Pin Arduino dengan menghubungkan output pin sensor ke pin Arduino digital.

\section{3) Tampilan TFT Nextion}

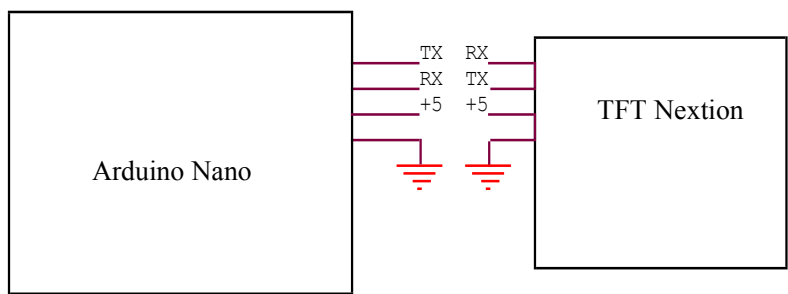

Fig. 5. Penghubung Tft Nextion ke pin Arduino

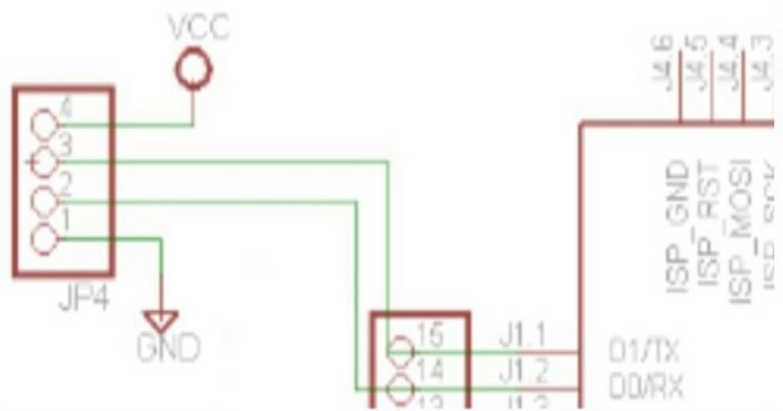

Fig. 6. Penghubung Tft Nextion ke pin Arduino

Pin TFT Nextion yang terhubung ke Arduino dengan menghubungkan pin Arduino TX ke TFT Nextion pin RX dan sebaliknya pin Arduino RX ke TX pin TFT Nextion

\section{HASIL}

Dalam penelitian ini, Modul Digital Pressure Meter (DPM) Dua Mode Dilengkapi Thermohygrometer dan Pemilihan Tekanan telah dilakuakan pengukuran dengan alat Tensimeter Air Raksa.

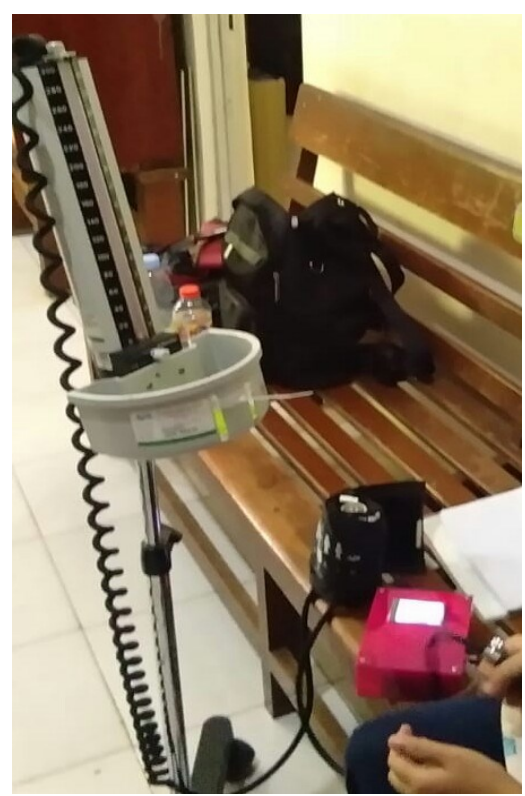

Fig. 7. Pengukuran pada tensimeter

\section{1) Desain Modul Digital Pressure Meter}

Modul Digital Pressure Meter ditunjukkan pada Fig. 8. Terdapat masing-masing penghubung dari output sensor. Tekanan maksimal dari Positive pressure adalah $300 \mathrm{mmHg}$. Terdapat sensor suhu kelembaban untuk mendeteksi suhu kelembaban pada saat melakukan pengukuran.Hasil ditunjukan pada display yang digunakan adalah LCD TFT Nextion. 


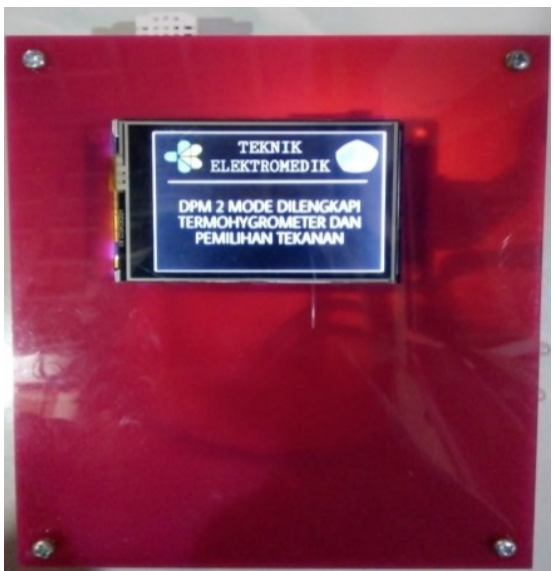

Fig. 8. Modul Digital Pressure Meter

\section{2) Program Arduino}

Listing Program 1. pembacaan nilai tekanan dari sensor MPX $5050 \mathrm{GP}$

\begin{tabular}{|c|}
\hline $\begin{array}{l}\text { void loop(void) } \\
\{ \\
\text { delay(50); } \\
\text { sensorValue = analogRead(sensorPin); } \\
\text { //pembacaan ADC sensor positif mpx5050GP } \\
\text { Vout = (sensorValue *5.0/1023.0)*1000; } \\
\text { //konversi data ADC ke tegangan Vout sensor } \\
\text { Value_Kpa=( Vout-165.29)/90; } \\
\text { //rumus Kpa disesuaikan dengan datasheet sensor } \\
\text { Value_mmHg =(Value_Kpa*7.5); } \\
\text { //1 Kpa =7.5 mmHg } \\
\text { static char tekananPositif[6]; } \\
\text { dtostrf(Value_mmHg, 3, 1, tekananPositif); } \\
\text { t9.setText(tekananPositif); } \\
\text { delay(50); }\end{array}$ \\
\hline
\end{tabular}

\section{Listing Program 2 Suhu, Kelembaban Sensor DHT 22}

void bupdatePopCallback(void *ptr) \{

// membaca kelembaban

float $\mathrm{h}=$ dht.readHumidity();

// membaca temperature suhu

float $\mathrm{t}=$ dht.readTemperature () ;

if (isnan(h) $\|$ isnan(t) $\|)\{$

return;

\}

static char temperatureCTemp[6];

$\operatorname{dtostrf}(\mathrm{t}, 6,2$, temperatureCTemp);

tTempC.setText(temperatureCTemp);

char hTemp $[10]=\{0\}$;

utoa(int(h), hTemp, 10);

tHumidity.setText(hTemp);

$$
\text { \} }
$$

3) Rata - rata Pengukuan Pada Tensimeter air Raksa

TABLE I. AIR RAKSA RATA- RATA HASIL PENGUKURAN PADA TENSIMETER

\begin{tabular}{|c|c|}
\hline $\begin{array}{c}\text { Tekanan } \\
(\mathrm{mmHg})\end{array}$ & $\begin{array}{c}\text { Rata-rata } \\
(\mathrm{mmHg})\end{array}$ \\
\hline 0 & 0 \\
\hline 50 & 48,2 \\
\hline 100 & 98,0 \\
\hline 150 & 148,8 \\
\hline 200 & 198,7 \\
\hline 250 & 247,7 \\
\hline 300 & 296,7 \\
\hline
\end{tabular}

\section{4) Konversi Satuan Tekana $\mathrm{mmHg}$ to $\mathrm{kPa}$}

TABLE II. HASIL KONVERSI MMHG TO KPA

\begin{tabular}{|l|l|l|l|l|}
\hline $\begin{array}{l}\text { Tekanan } \\
(\mathrm{mmHg})\end{array}$ & \multicolumn{2}{|c|}{$\begin{array}{c}\text { Pengukuran } \\
\mathrm{mmHg}\end{array}$} & \multicolumn{2}{c|}{ mmHg to kPa } \\
\hline & Naik 1 & Turun 1 & Naik 1 & Turun 1 \\
\hline 0 & 0,0 & 0,0 & 0,0 & 0,0 \\
\hline 50 & 48,0 & 49,0 & 6,4 & 6,5 \\
\hline 100 & 96,0 & 102,0 & 12,8 & 13,6 \\
\hline 150 & 150,0 & 149,0 & 20 & 19,8 \\
\hline 200 & 201,0 & 199,0 & 26,8 & 26,5 \\
\hline 250 & 248,0 & 248,0 & 33,1 & 33,1 \\
\hline 300 & 295,0 & 295,0 & 39,3 & 39,3 \\
\hline
\end{tabular}

Dari table diatas merupakan hasil konversi data pada tekanan positive, setiap naik atau turunya hasil di bagi 7,50062 untuk mendapat konversi ke $\mathrm{kPa}$. Dari hasil konversi tersebut hasilnya tidak selalu jauh apabila dihiung secara manual.

\section{5) Pengukuran Output Sensor MPX 5050 GP}

\section{TABLE III. HASIL OUTPUT SENSOR MPX $5050 \mathrm{GP}$}

\begin{tabular}{|c|c|c|c|}
\hline $\begin{array}{c}\text { V. Supply } \\
\text { ( Volt })\end{array}$ & $\begin{array}{c}\text { Tekanan } \\
(\mathrm{mmHg})\end{array}$ & \multicolumn{2}{|c|}{ V.Out Sensor ( Volt ) } \\
\cline { 3 - 4 } & & Naik & Turun \\
\hline 5,00 & 0 & 0,15 & 0,17 \\
\hline 5,00 & 50 & 0,67 & 0,65 \\
\hline 5,00 & 100 & 1.18 & 1.20 \\
\hline 5,00 & 150 & 1,71 & 1,70 \\
\hline 5,00 & 200 & 2.25 & 2.27 \\
\hline 5,00 & 250 & 2.67 & 2.69 \\
\hline 5,00 & 300 & 3.88 & 3.82 \\
\hline
\end{tabular}

Pengukuran Output Sensor MPX 5050GP menggunakan multimeter. 


\section{6) Pengukuran Suhu Kelembaban}

TABLE IV. PERBANDINGAN SUHU

\begin{tabular}{|l|l|}
\hline $\begin{array}{l}\text { Suhu Pada } \\
\text { Modul }\end{array}$ & $\begin{array}{l}\text { Suhu } \\
\text { Pada Thermohygrometer }\end{array}$ \\
\hline $31.0{ }^{\circ} \mathrm{C}$ & $30.7^{\circ} \mathrm{C}$ \\
\hline
\end{tabular}

TABLE V. PERBANDINGAN KELEMBAPAN

\begin{tabular}{|l|l|}
\hline $\begin{array}{l}\text { Kelembapan } \\
\text { Pada Modul }\end{array}$ & $\begin{array}{l}\text { Kelembapan pada } \\
\text { Thermohygrometer }\end{array}$ \\
\hline $87 \%$ & $86 \%$ \\
\hline
\end{tabular}

Pengukuran suhu dan kelembaban pada modul alat menggunakan alat pembanding Thermo-Hygrometer model :HTC-2 Pengujian dilakukan di ruang tertutup dan pengukuran dilakukan selama satu kali.

\section{DISKUSI}

Pengukuran tekanan positif yaitu $0-300 \mathrm{mmHg}$ dengan penurunan pertitik $50 \mathrm{mmHg}$. Pengukuran modul ini telah dilakukan pengambilan data pada alat tensimeter air raksa sebanyak 6 pengukuran kali lalu dihitung dan dapat dirata rata. Hasil data yang diperoleh menunjukan bahwa selisih dari pengukuran tidak jauh berbeda dari tekanan asli alat. Dan terdapatnya timer 1 menit (60 detik) memudahkan untuk melakukan tes uji kebocoran, karena timer uji kebocoran biasanya merupakan bagian eksternal dari alat tersebut. Pengukuran suhu kelembaban dilakukan pada ruangan pengukuran dilakukan hanya 1 kali pengukuran dengan alat pembanding hasil data yang didapatkan tidak terlalu jauh. Berdasarkan temuan yang diperoleh dari jurnal yaitu Pada Tahun 2019 Mukhamad Ryan Nur Rohman membuat tugas akhir tentang Digital Pressure Meter (DPM) Tensimeter dan Suction Pump, namun alat ini masih memiliki kekurangan yaitu timer uji kebocoran yang digunakan saat melakukan pengukuran pada tensimeter dan kekurangan suhu, kelembapan dalam kalibrasi [8]. Pada penelitian tersebut menggunakan LCD karakter untuk menampilkan hasil data pada DPM, tidak terdapat sensor DHT 22 sebagai sensor suhu kelembaban. Sehingga kurang efisien.

\section{Kesimpulan}

Dikembangkan Digital Pressure Meter (DPM) sebagai alat kalibrator tensimeter air raksa dan suction pump dengan Thermohygrometer dan pemilihan tekanan. Hal ini juga sebagai solusi untuk menciptakan perangkat pemantauan tekanan darah yang lebih informatif efektif serta akurat dalam pengukurannya. Secara menyeluruh penelitian ini dapat menyimpulkan bahwa Rangkaian keseluruhan yang dibuat sudah sesuai dengan kebutuhan modul DPM, yaitu hasil pengukuran tekanan positif yakni tekanan 0 sampai $300 \mathrm{mmHg}$ yang merupakan pengukuran pada alat tensimeter air raksa. Pengukuran dilakukan sebanyak enam kali. Pengukuran output sensor positive atau sensor Mpx 5050GP dilakukan dengan mengukur ouput sensor dan gnd sensor menggunakan multimeter.
Pengukuran suhu dan kelembaban merupakan pengukuran menggunakan Thermo-Hygrometer model : HTC-2 pengukuran ini dilakukan dengan cara membandingkan tampilan display pembacaan tekanan pada modul DPM DUA MODE.

\section{DAFTAR PUSTAKA}

[1] Turner, M. J., Speechly, C., \& Bignell, N. (2007). Sphygmomanometer calibration Why, how and how often? Australian Family Physician, 36(10), 834-837.

[2] O’Brien, E., Waeber, B., Parati, G., Staessen, J., \& Myers, M. G. (2001). Blood pressure measuring devices: Recommendations of the European Society of Hypertension. British Medical Journal, 322(7285), 531536. https://doi.org/10.1136/bmj.322.7285.531

[3] M. Ashworth, K. Gordon, G. Baker, and A. Deshmukh, "Sphygmomanometer calibration: A survey of one inner-city primary care group," J. Hum. Hypertens., vol. 15, no. 4, pp. 259-262, 2001.

[4] Prasetyo Wicaksono. (2015). Vacum, T., \& Positif. surabaya: POLTEKKES SURABAYA.

[5] Rosyi Dwi Putranti. (2016). Analisis Perbandingan Tensimeter

[6] Junia Dyah Permata Wibisono, Priyambada Cahya Nugraha, MT, Hj. Andjar Pudji, ST, M., \& ABSTRAK. (2017). " Digital Pressure Meter ( DPM ) Va cum Pressure ." Jurusan Teknik Elektromedik POLITEKNIK KESEHATAN KEMENTRIAN KESEHATAN SURABAYA.

[7] Yosep KurAkhir, S. T., Teknik, J., Politeknik, E., \& Surabaya, K. (2018). Dpm dua mode.

[8] Ryan, M., Rokhman, N., Irianto, B. G., \& Ariswati, H. G. (2019). DIGITAL PRESSURE METER. 1(1), 1-4.

[9] Bogdan, M. (2017). How to Use the DHT22 Sensor for Measuring Temperature and Humidity with the Arduino Board. ACTA Universitatis Cibiniensis, 68(1), 22-25. https://doi.org/10.1515/aucts-2016-0005

[10] Rabe, C. (2004). MEASUREMENT OF WATER ACTIVITY FROM SHALES THROUGH THERMOHIGROMETER Resumo 2 . Water Activity of Shale Ph . D ., Petroleum Geomechanics - GTEP / DEC / PUC-Rio 3 . Description of Shale's Individual Constituints. 1-8.

[11] Ridwan, A. C., \& Ariswati, H. G. (2019). DPM TWO MODES ARE EQUIPPED WITH TEMPERATURE AND HUMIDITY. 1, 1-5

[12] Pudji, A., \& Makruf, M. R. (2017). Design of the Digital Pressure Meter with Thermohygrometer. 7(9), 35-39. 
[13] Buchanan, S., Orris, P., \& Karliner, J. (2011). Alternatives to the mercury sphygmomanometer. Journal of Public
Health
Policy, $32(1)$, $107-120$

https://doi.org/10.1057/jphp.2010.

[14] Putri, A. R. (2020). FOOD WARMER SYSTEM BASED ON DHT-22. 4(1).

[15] J., O. E., O., I. O., O., O. O., \& O., O. (2016). Development of a real time blood pressure, temperature measurement and reporting system for inpatients. International Journal of Physical Sciences, 11(17), 225-232. https://doi.org/10.5897/ijps2016.4514

[16] Farhad Ismail, M., \& Sarkar, M. A. R. (2012). Development of a Model for Electronic Toll-Collection System. International Journal of Intelligent Systems and Applications, 4(1), 39-45. https://doi.org/10.5815/ijisa.2012.01.05

[17] Abba, S., \& Nyam, I. M. (2018). Design, implementation and performance evaluation of wireless sensor networks for data acquisition system ( A case study of smart homes ). September.

[18] Louis, L. (2016). Working Principle of Arduino and Using It As a Tool for Study and Research. International Journal of Control, 1(2), 21-29. https://doi.org/10.5121/ijcacs.2016.1203

[19] Bento, A. C. (2018). IoT of Nextion X TFT ILI9341: Experimental Results and Comparative Survey. International Research Journal of Engineering, IT \& Scientific Research, 4(2), 14-23. https://doi.org/10.21744/irjeis.v4n2.52

[20] Bento, A. C., Barros, A. R. de, Silva, É. O. L. da, \& Mantovani, L. A. T. (2019). NodeMCU12e + Nextion Tft an Experimental Survey with Virtual Keyboard in IoT Projects. International Journal of Advanced Engineering Research and Science, 6(1), 38-44. https://doi.org/10.22161/ijaers.6.1.7 